\title{
THE MESOPROTEROZOIC VOLCANO-SEDIMENTARY SERRA DO ITABERABA GROUP OF THE CENTRAL RIBEIRA BELT, SÃO PAULO STATE, BRAZIL: IMPLICATIONS FOR THE AGE OF THE OVERLYING SÃO ROQUE GROUP
}

\section{CAETANO JULIANI ${ }^{1}$, PETER HACKSPACHER ${ }^{2}$, ELTON LUIZ DANTAS ${ }^{3}$, ALLEN HUTCHESON FETTER ${ }^{2}$}

\begin{abstract}
One of the fundamental problems to understanding the evolution of volcano-sedimentary sequences in southeastern Brazil is constraining their depositional ages. Brasiliano tectonic and metamorphic overprinting either obscured or destroyed primary features, such as unconformities, as well as other geologic relationships. This problem is exemplified by the Serra do Itaberaba and São Roque groups, where the lack of data about the timing of their deposition has prevented resolution of proposed one- and two-stage geotectonic/depositional models. Recent U-Pb zircon data obtained from metavolcanic rocks in the São Roque Group indicate that it was deposited between 628 and $607 \mathrm{Ma}$ New U-Pb zircon data of $1395+10 \mathrm{Ma}$ for a metandesite in the basal Morro da Pedra Preta Formation (Serra do Itaberaba Group) indicate the maximum age for the beginning of the deposition of the pelites overlying MORB-like basalt. A metarhyolite of the upper unit, the Nhanguçu Formation, contains two zircon populations. One yielded an age of $619 \pm 3 \mathrm{Ma}$, which defines the crystallization age of the rock, and the other an age of $1449 \pm 3 \mathrm{Ma}$, interpreted as inherited xenocrystal grains from older units of the Serra do Itaberaba Group. The younger metarhyolite was affected only by the $\mathrm{S}$ foliation, generated during the Brasiliano orogenesis, whereas the Middle Proterozoic metavolcano-sedimentary sequence records additional metamorphic and deformational events, confirming the presence of two different geotectonic cycles.
\end{abstract}

Keywords: U-Pb geochronology, metandesite, metarhyolite, Serra does Itaberaba Group, São Roque Group

INTRODUCTION Previous geochronological studies of the Ribeira Belt primarily focused on obtaining the ages of granitic, gneissic and migmatitic rocks, e.g., Almeida et al. (1976) and Hasui et al. (1984), to help establish its geotectonic evolution. Only recently, however, have systematic studies been carried on to constrain deposition ages for the Precambrian supracrustal sequences in the orogen. U-Pb zircon geochronological data obtained from metavolcanic rocks in these sequences provide an important means to solve lithostratigraphic relationships and tectonic problems.

The Serra do Itaberaba (SIG) and São Roque (SRG) groups are two major lithostratigraphic units in the State of São Paulo (Fig. 1). The ongoing debate about the stratigraphic relationship of these units has focused on whether or not an age gap separates the deposition of these two groups (Coutinho 1955, Almeida et al. 1981, Hasui 1981, Juliani et al. 1986).

According to Juliani et al. (1986) the SIG is composed of a volcano-sedimentary sequence and is more intensely deformed than the metasediments of SRG, usually with $\mathrm{S}_{0} / \mathrm{S}_{2}$ fabrics, and recording medium-grade Barrovian metamorphism. In contrast, the SRG contains $\mathrm{S}_{1} / \mathrm{S}_{0}$ fabrics without stratigraphic inversions, and abundant sedimentary structures are preserved. Furthermore, the mineral assemblages of the SRG indicate that it was only subjected to greenschist facies metamorphism.
Some K-Ar geochronological data from lato sensu SRG lithologies suggest that it was deposited at $1.4 \mathrm{Ga}$, with metamorphism occurring between 650-600 Ma (Cordani \& Bittencourt 1967, Cordani \& Teixeira 1979). Subsequent K-Ar data for SIG metamafic rocks supplied an age of $1690+157 \mathrm{Ga}$ (Juliani et al. 1986), suggesting that deposition and metamorphism of the volcano-sedimentary sequence occurred prior to the deposition of SRG.

Van Schmus et al. (1986) obtained U-Pb zircon age of $1790+14$ Ma from the Polvilho Hill metarhyodacite that is intercalated in the basal part of the SRG. The age was interpreted as representing magmatic crystallization, indicating that the deposition of SRG began around $1.8 \mathrm{Ga}$, hence precluding a Neoproterozoic depositional age for the SRG. More detailed mapping and petrography, however, show that the apparent metarhyodacite is actually a meta-arkose that is intercalated with metaconglomerates in the basal portion of the SRG (Juliani et al. 1997). The zircon grains in the arkose are mostly rounded, detrital, which means that they place a maximum depositional age on the SRG, not the actual age of the onset of sedimentation.

Based on U-Pb, Rb-Sr and K-Ar data, Tassinari (1988) proposed that the deposition of the volcano-sedimentary sequence of the São Roque/Serra do Itaberaba belt began at $1.8 \mathrm{Ga}$ and was followed by two magmatic-metamorphic events between $1.3-1.0 \mathrm{Ga}$ and $800-720$

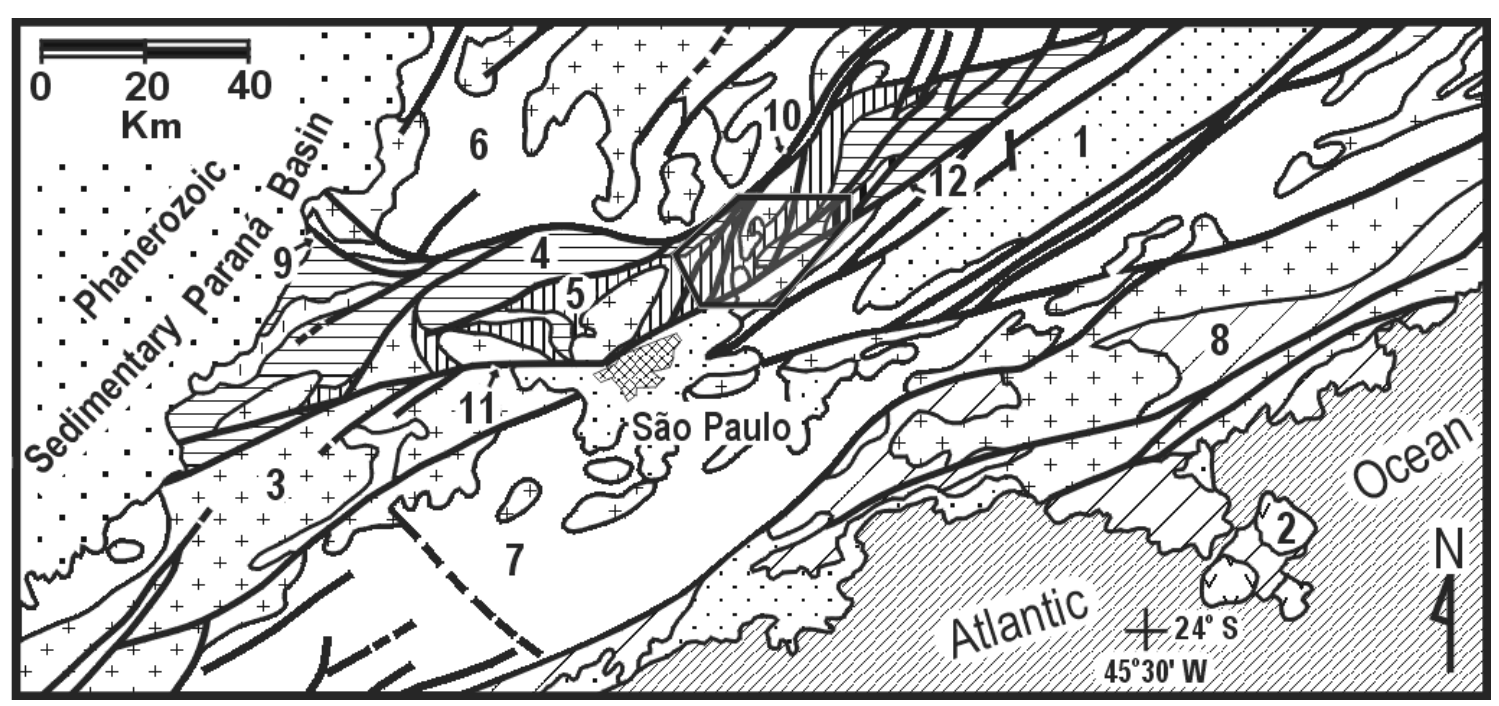

Figure 1 - Regional geological map. (1) Tertiary and quaternary sediments, (2) Mesozoic alkaline intrusions, (3) Brasiliano granitoids, (4) São Roque Group, (5) Serra do Itaberaba Group, (6) Amparo, Paraíba do Sul and Itapira groups and Igaratá Complex, (7) Embú Complex and (8) Costeiro Complex. Lines represent the main transcurrent shear zones: (9) Itú, (10) Jundiuvira, (11) Taxaquara and (12) Rio Jaguari (modified from Almeida et al. 1981).

1 - Instituto de Geociências - USP, Rua do Lago 562, Cidade Universitária, CEP 05508-900, São Paulo, SP, FAX 0xx 11 8184248, e-mail cjuliani@usp.br

2 - Instituto de Geociências e Ciências Exatas - UNESP, Av. 24, 1515, CEP 13506-900, Rio Claro, SP, Fax 0xx19 5262831, e-mails: phack@ rc.unesp.br and fetter@rc.unesp.br

3 - Instituto de Geociências - UnB, Brasília, DF, e-mail: elton@unb.br 


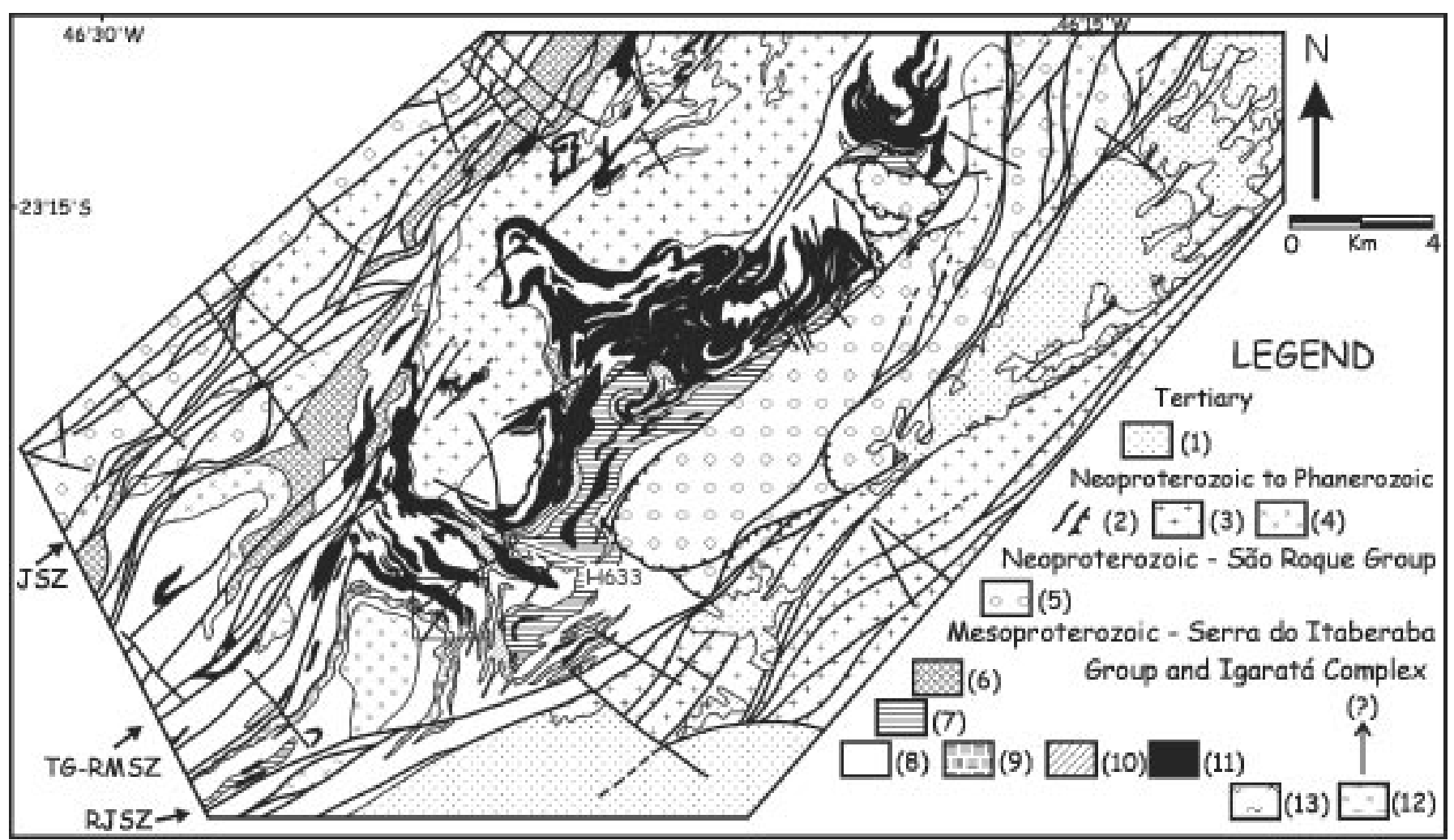

Figure 2 - Geological sketch of the Itaberaba and Pedra Branca hills (Juliani 1993) showing the location of the analyzed metarhyolite (sample H633). Legend: (1) Sediments of the São Paulo Basin, (2) Wrench, normal and thrust shear zones, (3) Granitoids of the Porphyritic Suit (4) Non Porphyritic and (5) São Roque Group. The Serra do Itaberaba Group is constituted by the Pirucaia Fm. (6), Nhangucu Fm. (7) and Morro da Pedra Preta Fm. with metapelite (8), BIF (9), tuffaceous metasediments (10) metamafic rocks and metatuffs (11), metagranitoids (12), discordantly to the Igaratá Complex (13) and shear zones (JSZ) Jundiuvira, (RJSZ) Rio Jaguari and (TGRMSZ) Tanque Grande - Ribeirão dos Macacos.

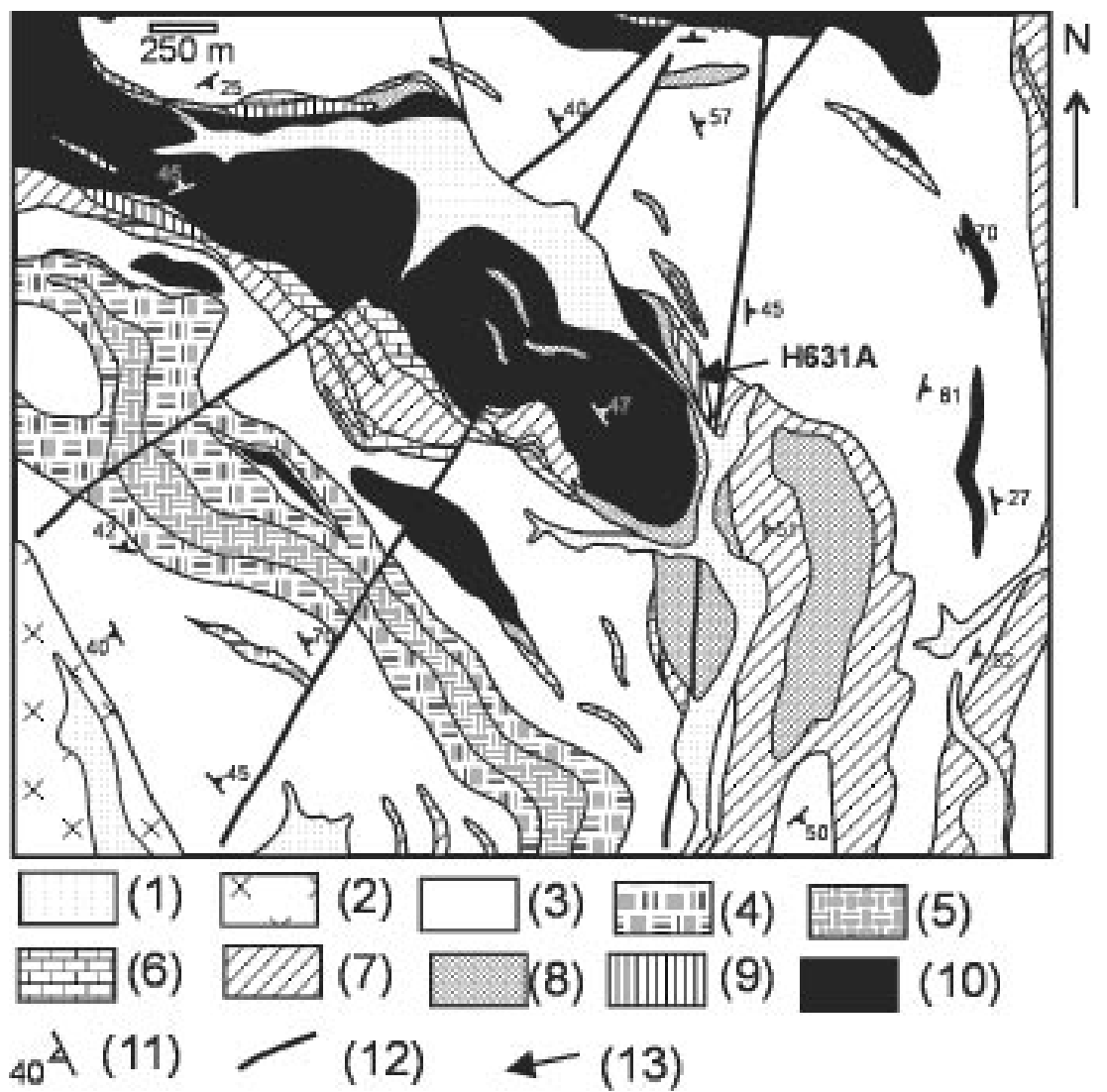

Figure 3 - Detailed geological map of the area where the metandesite was sampled (H631A) in the Serra do Itaberaba Group (Juliani 1993). (1) Quaternary alluvium, (2) Pau Pedra Granitoids - Non Porphiritic Suit, (3) Metapelites, (4) BIF-manganesiferrous facies, (5) BIF-silicate and oxide facies, (6) Calc-silicate rocks, (7) Tuffaceous metasediment, (8) Metatuff and volcanic metaconglomerates, (9) Metandesite to metarhyodacite, (10) Metamafic rocks, (11) $S_{0} / S_{1}$ attitude, (12) Normal faults, (13) Sampled outcrop. 
Ma, with a final phase of magmatism occurring from 620 to $550 \mathrm{Ma}$.

Detailed field studies and recent $\mathrm{U}-\mathrm{Pb}$ zircon ages from metamafic rocks of the SRG suggest that it represents a Neoproterozoic back-arc basin sequence (Hackspacher et al. 1999, Dantas et al. 1999). New U$\mathrm{Pb}$ zircon results from basal metavolcanic rocks of the SIG now place constraints on the timing of its deposition as well. These new data provide important controls for reconstructing the geotectonic evolution of the Ribeira Belt.

GEOLOGICAL SYNTHESIS SIG and SRG host rocks are Paleoproterozoic gneisses and migmatites that are intruded by Neoproterozoic plutons. Figure 2 shows the relationships between the SIG and SRG and the surrounding geology in detail. Short descriptions of the main units of SIG and SRG, as well as granitic rocks are presented below:

Serra do Itaberaba Group MORRO DA PEDRA PRETA FORMATION (MPPF) This basal unit is composed mainly of metamafic and metapelitic rocks, with subordinate occurrences of calcsilicate and metavolcaniclastic rocks, graphitic and sulfur-rich metapelites, banded iron formations, metandesite, metarhyolite, tourmalinite and metahydrothermalites derived from mafic and felsic rocks. The basal metamafic unit is composed mainly of plagioclasehornblende schist or hornblende amphibolite, sometimes with garnet and diopside, with some igneous or volcaniclastic textures preserved. Locally there are metaspilite bodies, pillow lavas and, very rarely, small vesicles, indicating eruptions in deep-sea water. The mafic to intermediate metavolcaniclastic rocks vary from volcanic metaglomerate to fine-grained metatuff, sometimes mixed with pelites. Metahyaloclastite lenses are also present.

The metapelitic unit is composed predominantly of muscovite and/ or biotite laminated to banded schists, thick- to fine-grained, commonly with garnet, staurolite, kyanite, sillimanite and cordierite porphyroblasts. K-feldspar is sometimes present in the rocks of higher metamorphic grade. Frequently there are small intercalations of metatuff, ferruginous, manganesiferous, graphitic and carbonaceous metasediments, BIFs and metachert.

Extensive banded or laminated tuffaceous metasediments are deposited over basaltic units. Small intercalations of metatuffs, metachert, tourmalinite, iron formation, manganesiferous, magnetitic and sulfurous bands are locally present. They are composed of lenses containing chlorite, hornblende, plagioclase, quartz, biotite and epidote, and subordinate lenses of biotite-rich schist.

The intermediate to felsic rocks occur as small lenses on the top of the basaltic crust, usually affected by hydrothermal processes prior to metamorphism, forming associations as garnet-cordieritecummingtonite-anthophillite amphibolites and margarite-corundum schist. The forms of the bodies and the arrangement of the hydrothermally altered rocks indicate an origin related to old pipes intrusive in the basaltic crust and tuffs (Pérez-Aguilar 1996). Above and laterally there are volcanic metaglomerates grading to andesitic/ rhyodacitic metatuffs that are covered by schists, commonly sulfurous and graphitic, and calc-silicate rocks.

The calc-silicate rocks occur as lenses usually adjacent to metandesitic and metadacitic bodies, and are composed of tremolite, actinolite, diopside, quartz, hornblende, carbonate, plagioclase, phlogopite and garnet. The iron formations are represented by ferruginous metachert or itabirites with hematite and magnetite. The larger bodies are formed by Algoma BIF type, with rich beds of grunerite or ferriferous/manganesiferous cummingtonite, garnet and magnetite, with metachert or magnetite-rich intercalations. These rocks grade into manganesiferous facies both upwards and laterally (Fig. 3).

NHANGUÇU FORMATION (NF) Is positioned concordantly over the MPPF, with possible local angular discordance, or discordantly, through tectonic contacts. It consists of a lower unit of ironmanganesiferous metapelite that grade to calcium-rich pelites with lenses of carbonate rocks, metatuffs, metabasalt and small metarhyolite bodies. The upper unit is composed of fine rhythmitic schists containing quartz-rich lenses of muscovite, clorite, quartz and andalusite.

PIRUCAIA FORMATION (PF) Is composed primarily of larger quartzite bodies with intercalations of quartz-rich metapelite, feldspatic

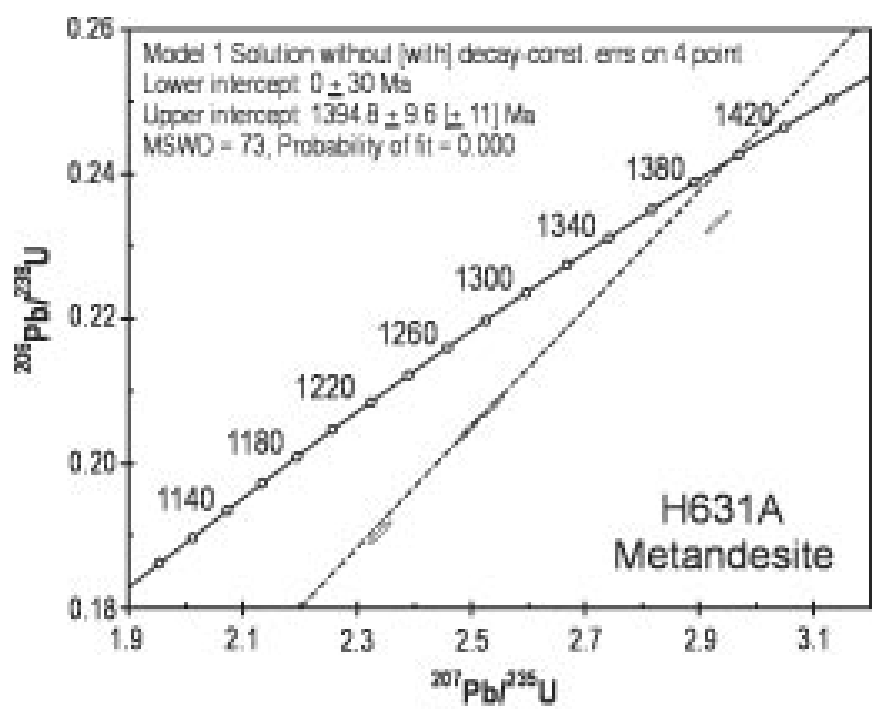

Figure 4 - Concordia diagram for zircon grains from metandesite (sample H631A) from the Morro da Pedra Preta Formation.

Table $1-(1) N M=$ nonmagnetic, number in parenthesis indicate side tilt used on Frantz separator at 1.5 amp. Power first number $=1$ D\# on Figures 4 an 5 , (2) Total $U$ and Pb concentrations corrected for analytical blank; (3) Not corrected for blank or non-radiogenic Pb; (4) Radiogenic Pb corrected for blank and initial Pb:U corrected for blank; (5) Ages given in Ma using decay constants recommended by Steiger and Jäger (1977).

\begin{tabular}{|l|c|c|c|c|c|c|c|c|c|c|}
\hline \multicolumn{3}{|c}{$\begin{array}{c}\text { Concentrations } \\
(2)\end{array}$} & $\begin{array}{c}\text { Observed } \\
(3)\end{array}$ & \multicolumn{3}{c|}{$\begin{array}{c}\text { Atomic Ratios } \\
(4)\end{array}$} & \multicolumn{3}{c|}{$\begin{array}{c}\text { Ages (Ma) } \\
(5)\end{array}$} \\
\hline $\begin{array}{c}\text { Fraction } \\
(1)\end{array}$ & $\begin{array}{c}\text { Size } \\
(\mathrm{mg})\end{array}$ & $\begin{array}{c}\mathrm{U} \\
(\mathrm{ppm})\end{array}$ & $\begin{array}{c}\mathrm{Pb} \\
\mathrm{ppm})\end{array}$ & $\begin{array}{c}{ }^{206} \mathrm{~Pb} \\
{ }^{204} \mathrm{~Pb}\end{array}$ & $\begin{array}{c}{ }^{206} \mathrm{~Pb} \\
{ }^{238} \mathrm{U}\end{array}$ & $\begin{array}{c}{ }^{207} \mathrm{~Pb} \\
{ }^{235} \mathrm{U}\end{array}$ & $\begin{array}{c}{ }^{207} \mathrm{~Pb} \\
{ }^{206} \mathrm{~Pb}\end{array}$ & $\begin{array}{c}{ }^{206} \mathrm{~Pb} \\
{ }^{238} \mathrm{U}\end{array}$ & $\begin{array}{c}{ }^{207} \mathrm{~Pb} \\
{ }^{235} \mathrm{U}\end{array}$ & $\begin{array}{c}{ }^{207} \mathrm{~Pb} \\
{ }^{206} \mathrm{~Pb} \\
(+-2 \sigma)\end{array}$ \\
\hline H631A & & & & & & & & & & \\
\hline $\mathrm{M}(0) 75$ & 0.016 & 2084 & 550 & 2740 & 0.20530 & 2.5015 & 0.08849 & 1202 & 1272 & $1393(1)$ \\
\hline $\mathrm{M}(0) 13$ & 0.004 & 1155 & 255 & 1043 & 0.19048 & 2.3413 & 0.08915 & 1124 & 1225 & $1407(2)$ \\
\hline $\mathrm{M}(1) 76$ & 0.006 & 1755 & 528 & 1180 & 0.23343 & 2.9327 & 0.09112 & 1352 & 1390 & $1449(1)$ \\
\hline $\mathrm{M}(2) 6$ & 0.013 & 1329 & 343 & 992 & 0.20423 & 2.4927 & 0.08852 & 1198 & 1283 & $1394(2)$ \\
\hline $\mathrm{M}(3) 7$ & 0.010 & 747 & 211 & 2078 & 0.20784 & 2.5386 & 0.08859 & 1217 & 1283 & $1395(1)$ \\
\hline $\mathbf{H 6 3 3}$ & & & & & & & & & & \\
\hline $\mathrm{M}(1) 11$ & 0.006 & 305 & 37 & 144 & 0.09002 & 0.7606 & 0.06128 & 556 & 574 & $649(10)$ \\
\hline $\mathrm{M}(0) 14$ & 0.022 & 323 & 34 & 1040 & 0.09902 & 0.8263 & 0.06052 & 609 & 612 & $622(3)$ \\
\hline $\mathrm{NM}(0) 15$ & 0.009 & 2533 & 240 & 684 & 0.08455 & 0.7180 & 0.06159 & 523 & 550 & $660(8)$ \\
\hline
\end{tabular}


quartzite and, more rarely, small bodies of metarkose. The quartzite bodies grade into quartz-rich garnet-sillimanite schist containing some biotite. The quartz schist contain rhythmic structures similar those of turbidites.

São Roque Group It belongs to the Piragibu Formation (PiF), according to Juliani \& Beljavskis (1995), partially redefined here. This group is dominated by feldspatic metarhytmites, with small intercalations of phyllite, sometimes graphitic, slate, metarenite, metarkose, rare metamafic bodies and lenses of polymictic metaconglomerate to metabreccia in the base. It is in contact with SIG through wrench or thrust shear zones, but occasionally the contacts appear to represent unconformities based on fragments of metamafic flintstones and schists, identical of the lithologies of the SIG, in the basal metaconglomerate of the SRG.

Granitoid rocks PORPHYRITIC SUITE These plutonic units intruded subsequent to SIG $\mathrm{S}_{2}$ foliation, but commonly record a subsequent foliation of cataclastic or mylonitic textures. Typically coarse-grained and pink to gray-colored, these units are predominantly of granitic compostion (3b), with granodiorites and monzonites occurring locally.

NON-PORPHYRITIC SUITE These granitic lithologies are mediumto coarse-grained, inequigranular, clear gray to pink in color with compositions varying between tonalitic to granitic. The contacts with MPPF rocks are mainly tectonic.

METAGRANITOIDS Metagranitoids crop out as dark gray rocks, with strong gneissic or mylonitic foliation, commonly with sub-horizontal attitude, probably, related to the thrust event of the SRG over the SIG. These rocks are primarily granodioritic to tonalitic in composition, more rarely granitic, and commonly rich in biotite and hornblende.

Mylonitic and Cataclastic Rocks These rocks are related to the Jundiuvira, Rio Jaguari and Ribeirão dos Macacos-Tanque Grande shear zones and their smaller shear conjugates. Mylonites, derived from granitic and metamorphic rocks, are the most prevalent fabrics, but cataclastic and ultramylonitic fabrics are sometimes present.

PETROGRAPHY AND GEOCHRONOLOGY The metandesite of the Morro da Pedra Preta Formation is stratigraphically above the basal MORB-like metamafic unit (Fig. 3), and is interpreted to be a small intrusion linked with the beginning of the sedimentation in the Serra do Itaberaba basin. The metandesite is a fine- to medium-grained volcanic rock that varies in composition from quartz andesite to dacite, and commonly is composed of oligoclase-andesine, hornblende and quartz, besides garnet, biotite, chlorite, epidote, magnetite, ilmenite, sulfides, opaque, zircon, allanite, titanite, apatite and subordinate tourmaline. The metandesite body grade into neighboring thick metavolcaniclastic and the volcanic rocks, all of which suffered a strong hydrothermal alteration prior to medium-grade metamorphism Metapelite and calc-silicate rocks are concordantly overprinted, without indications of hydrothermal alterations, indicating that they were deposited after the eruption/intrusion of the metandesite.

Five zircon fractions from the metandesite, yield an upper intercept age of $1395 \pm 10 \mathrm{Ma}$ (Fig. 4 and Table 1), which is interpreted as the crystallization age of the metavolcanic rock. This value places a maximum age constraint to the onset of sedimentation that followed basaltic eruptions in an oceanic ridge environment.

Metarhyolite of the Nhanguçu Formation A two meter-thick body of highly weathered metarhyolite was collected for $\mathrm{U}-\mathrm{Pb}$ zircon age determinations. Contacts between the metavolcanic rock and surrounding manganesiferous metapelite are subconcordant with the compositional banding transposed by $\mathrm{S}_{2}$ that dismembered and stretched parts of the metarhyolite. This foliation was defined by Juliani (1993) as tectono-metamorphic reworking of SIG by the São Roque event, as the associated minerals are indicative of a progressive regime of low pressure with a clockwise P-T-t evolution, superimposed to the paragenesis of Barrovian regime present in $S_{1}$, also with clockwise history, characteristic of the SIG event.

Petrographically the metarhyolite is composed of fine-grained quartz and muscovite, tiny zircon crystals, tourmaline and opaque minerals, and relict feldspar grains. About 2 to $5 \%$ of quartz crystal relicts show bipyramidal terminations and magmatic corrosion features.

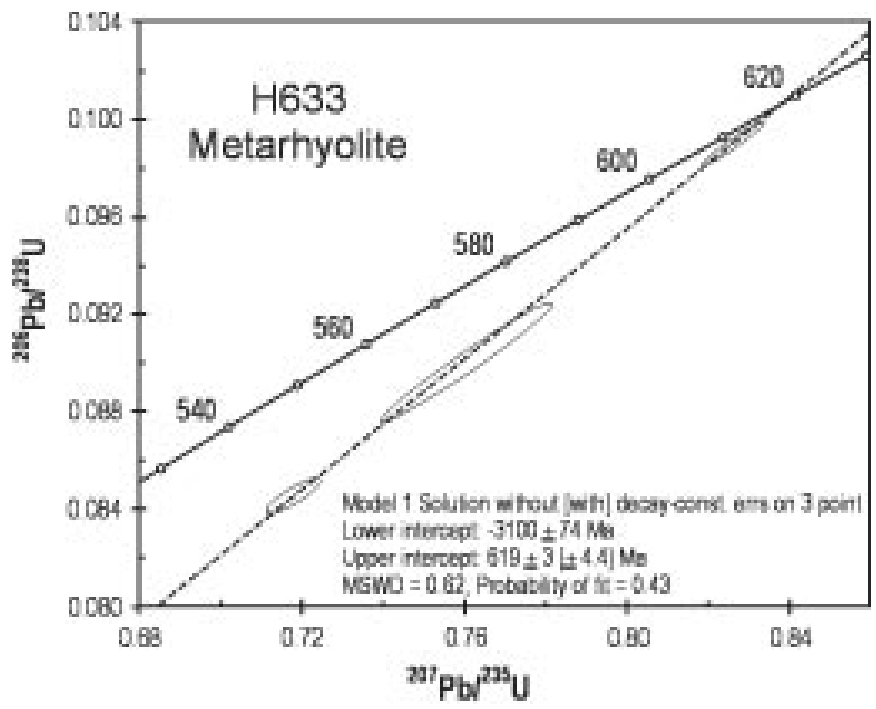

Figure 5 - Concordia diagram for magmatic zircon grains from metarhyolite (sample H633) from the Nhanguçu Formation.

Two zircon populations are present, one of them colorless to rosy, with age of $1449 \pm 3 \mathrm{Ma}$ and another of prismatic colorless crystals, with age of $619 \pm 3$ Ma (Fig. 5 and Table 1). The older age is interpreted as reflecting inherited xenocrystals from SIG, and the younger age, as the crystallization age of the rhyolite. Such results refute the interpretations of Juliani et al. (1996) that considered them as metavolcanics of NF. This younger age indicates that the rhyolite is intrusive in the formation.

DISCUSSION AND CONCLUSIONS The U-Pb age of $1395 \pm$ $10 \mathrm{Ma}$ obtained from the basal metandesite of the SIG indicates that sedimentation and volcanism occurred during the Mesoproterozoic, prior to the SRG, whose deposition began at about $628 \mathrm{Ma}$ (Hackspacher et al. 1999). These new data support previous field observations, metamorphic and stratigraphic, that suggested distinctive age differences between both groups. Based on previous studies by Juliani (1993) and Juliani et al. (1997), it appears that the principal volcanic event of MPPF took place in normal segments of oceanic middle ridges, in a depositional basin similar to the one of the Gulf of Aden, compared with Pearce (1982) geochemical data. The metamorphosed intermediate rocks, in spite of their hydrothermal alteration, suggest an origin from partial melting of oceanic crust in an ensimatic subduction environment, in a back-arc setting, at the beginning of NF deposition (Juliani 1993). Initial depostion began in a shallow marine environment, with some local subaerial exposure. Features seen in the basal units indicate that they were exposed to exhalative activity. Deposition of iron-manganesiferous sediments and, the rhythmic structures of the fine-grained schists with andalusite on the top also suggest deposition by proximal turbiditic currents. Due offset along shear zones shear zones, PF stratigraphic positioning is unclear, but the formation corresponds mainly to the coastal facies of the basin. The possible metaturbidites in the top of the MPPF suggest that their deposition began early in relation to the opening of the basin, but its main phase of deposition occurred during the back-arc period, being therefore correlative to NF. Several geochemical analyses suggest that the source area for MPPF metapelites was a volcanic arc whereas for PF it was predominantly continental (Juliani 1993). Subsequent to deposition of the SIG, a tectonometamorphic event of unknown age affected the group. Studies of the younger SRG indicate that it was deposited on part of the SIG following this metamorphic event. The assemblage of sedimentary and igneous units in the SRG is consistent with deposition in a small ocean basin and is interpreted as a record of back-arc basin development during the active collisional phase of the Neoproterozoic Brasiliano orogeny (Hackpacher et al. 1999).

Acknowledgments To FAPESP (grants 93/4550-0, 971397-7, 99/00358-3) and CNPq (grants 400490/94-3, 522386/95-4) for financial support, and to two anonymous referees of RBG for critical review of the manuscript. 


\section{References}

Almeida F.F.M. de, Hasui Y., Brito Neves B.B. 1976. The upper Precambrian of South America. Boletim do Instituto de Geociências da Universidade de São Paulo, 7:4580 .

Almeida F.F.M. de, Hasui Y, Ponçano W.L., Dantas A.S.L., Carneiro C.D.R., Melo M.S. de Bistrichi C.A. 1981. Mapa Geológico do Estado de São Paulo, escala 1:500.000 Nota Explicativa. Instituto de Pesquisas Tecnológicas do Estado de São Paulo, 126p.

Bergmann M. 1988. Caracterização estratigráfica e estrutural da seqüência vulcanosedimentar do Grupo São Roque na região de Pirapora do Bom Jesus, Estado de São Paulo. Instituto de Geociências, Universidade de São Paulo, Dissertação de Mestrado, $155 \mathrm{p}$

Cordani U.G. \& Bittencourt I. 1967. Determinaç̃es de idades potássio-argônio em rochas do Grupo Açungui. In: SBG, Congresso Brasileiro de Geologia, 21, Curitiba, Anais, p. $218-233$.

Cordani U.G. \& Teixeira W. 1979. Comentários sobre as determinações geocronológicas existentes para as regiões das folhas Rio de Janeiro, Vitória e Iguape. In: Schobbenhaus Filho C. (Coord). Carta Geológica do Brasil ao Milionésimo, Folhas Rio de Janeiro ( $S F-23)$, Vitória ( $S F-24)$ e Iguape ( $S G-23)$, MME/DNPM, p. 175Rio 207.

Coutinho J.M.V. 1955. Sobre o metaconglomerado dos arredores de São Paulo. Engenharia, Mineração e Metalurgia., 21(121):15-16

Dantas E.L., Hackspacher P., Godoy A.M., Sato K., Pimentel M.M., Oliveira M.A.F., Fette A. 1999. Characterization of the generating sources of continental crust of the Ribeir Belt through isotope of Nd in the State of São Paulo, SE of Brazil In: SouthAmerican Symposium on Isotope Geology, 2, Villa Carlos Paz, Argentina, Anais, p 192-195.

Hackspacher P., Dantas E.L., Godoy A.M., Oliveira M.A.F., Fetter A., Van Schmus W.R. 1999. Considerations about the evolution of the Ribeira Belt in the São Paulo State - Brazil, from U/Pb geochronology in metavolcanic rocks of the São Roque Group In: South-American Symposium on Isotope Geology, 2, Villa Carlos Paz, Argentina, Anais, p. 310-313

Hasui Y. 1981. Mapa de Jazidas e Ocorrências Minerais do Estado de São Paulo - Texto Explicativo. Instituto de Pesquisas Tecnológicas do Estado de São Paulo, $349 \mathrm{p}$.

Hasui Y. Fonseca M.J.G., Ramalho R. 1984. A parte central da Região de Dobramento Sudeste e o Maciço Mediano de Guaxupé. In: Schobbenhaus C., Campos D. de A., D.

Juliani C. 1993. Geologia, petrogênese e aspectos metalogenéticos dos grupos Serra do Itaberaba e São Roque na região das serras do Itaberaba e da Pedra Branca, NE da cidade de São Paulo, SP. Instituto de Geociências, Univiversidade de São Pau1o, Tese de Doutoramento, $803 \mathrm{p}$.

Juliani C. \& Beljavskis P. 1995. Revisão da litoestratigrafia da Faixa São Roque/Serra do Itaberaba (SP). Revista do Instituto Geológico, 16:33-58.

Juliani C., Beljavskis P., Schorscher H.D. 1986. Petrogênese do vulcanismo e aspectos metalogenéticos associados: Grupo Serra do Itaberaba na região do São Roque. In SBG, Congresso Brasileiro de Geologia, 34, Goiânia, Anais, 2:730-743.

Juliani C., Pérez-Aguilar A., Martin M.A.B, Beljavskis P. 1996. Ocorrência e petrografia dos metarriólitos da Formação Nhanguçu - Grupo Serra do Itaberaba (SP). Revista Brasileira de Geociências, 26:113-116.

Juliani C., Martin M.A.B., Clarimundo S. de J. 1997. Os metarcóseos do Morro do Polvilho: implicações para geocronologia e para evolução crustal dos grupos Serra do Itaberaba e São Roque (SP). Anais da Academia Brasileira de Ciências, 69:441.

Pearce J.A. 1982 - Trace element characteristics of lavas from destructive plate boundaries. In: Thorpe R.S. (Ed.) Andesites, Orogenic andesites and related rocks. Chichester, John Wiley \& Sons, p. 525-548.

Pérez-Aguilar A. 1996. Geologia, petrografia e gênese dos granada-cordieritacummingtonita/antofilita anfibolitos e rochas associadas do Grupo Serra do cummingtonita/antofilita anfibolitos e rochas associadas do Grupo Serra do Mestrado, $168 \mathrm{p}$.

Ragatki D. 1998. Contribuição à geoquímica e geocronologia do Domínio São Roque e da Nappe de Empurrão Socorro - Guaxupé na região de Igaratá e Piracaia, SP. Instituto de Geociências, Universidade de São Paulo, Tese de Doutoramento, 130p.

Steiger R.H. \& Jäger E. 1977 - Subcommission on Geochronology: Convention in the use of decay constants in geo- and cosmochronology. Earth and Planetary Science Letters. 36:359-362.

Tassinari C.C.G. 1888. As idades das rochas e dos eventos metamórficos da porção sudeste do Estado de São Paulo e sua evolução crustal. Instituto de Geociências, Universidade de São Paulo, Tese de Doutoramento, 236p.

Van Schumus W.R., Tassinari C.C.G., Cordani U.G. 1986. Estudo geocronológico da parte inferior do Grupo São Roque. In: SBG, Congresso Brasileiro de Geologia, 34, Goiânia, Anais, 3:1399-1406.

Contribution IGC-112

Received March 2, 2000 Accepted for publication April 27, 2000 